ing gain in general strength and digestive power, and in a few weeks the patient was well.

Not to go further into detail, I have seen in consultation during the past eighteen months five cases nf scurvy in children aged eighteen, twenty, twenty-two, sixteen, and fourteen months, respectively, which illustrate ths etiological point in question. In ench of thess cases the food was properly proportioned and had for its basis sound cow's milk, hut sterilization had heen uniformly employed in its preparation. All recovered rapidly upon the same food unsterilized, with the addition of a small quantity of raw heef-juice and orange juice to the diet.

\title{
CRANIOTOMY FOR EPILEPSY AND ALLIED CONDITIONS.'
}

\author{
Br R. J. HALL, M.D. \\ OF SASTA BARBAEA, CAL.
}

The term used in this paper is cranintomy, and not craniectomy, as usually printed. Craniectony, which would mean excision of ths skull, seems to me ill-chosen.

I have the following six cases of craniotomy to report:

Oateoplastic resection of skull for epilepsy. Daphne S., aged two years and seven months. July 19, 1893. June, 1892, whils running across room fell, striking right side of head against wooden edge of sofa; was unconscious for some hours, then violent general convulsions all night; after convulsions left bemiplegin, which granlually disappeared.

June 7,1893 . Well-nourished child; speaks only one or two words; pnresis of left hand and forearm, and wenkness of left leg. Mother reports that two to five times daily child, while playing, will stop suddenly, eyes hecome fixed, head turn to one side (which side not noticed), have spasin of left arm, usually continue playing without paying attention; sometines fall down. Ordered antipyrine, gr. vi., in two doses, taken in the morning. After two weeks, no improvement occurring, ordered sod. hrom., gr. $\mathbf{x}$., in two doses, as hefore.

July 17 th. Mother reports no improvement; spasms more frequent and violent; child more often falls during apasms, nnd cries nfter them.

Operation, July 19th, Drs. Ottn, Cavel, H. nnd Ida Stambach assisting. Chloroform; usual aseptic precautions. Fissure of Rolando and motor nren of left arm determined hy Chiene's method. Tongue-shaped flap over motor nrea of left arm, with hase downward, including scalp and hone turned down; no adhesion nf dura mater; no pulsation on exposure of dura mater; ineised dura mntcr, which was much thickened, when organized clot (œdematous) about $\frac{1}{8}$ inch thick found, closely connected with pia mater; hone cut nway in direction upward and forward to determine extent of clot for distance of ahout $\stackrel{t}{\text { inch }}$; much serum exuded from odemntous pia mnter nn scarification; dura mater

1 Read before the Southern Callfornin Mredien Associalton, Los Angeles, June 5, 1895. 
sutured loosely witb interrupted catgut suture; continuous catgut suture of scalp-bone. wbich hnd entirely separnted, heing replnced; iodoform nnd aseptic gauze dressing; 6 P.s., temperature, $99^{\circ}$; pulse, 120 ; general condition good.

December $30 \mathrm{l} h$. Dressing removed two weeks after operation no general or local renction hnving followed, except slight rise of temperature (patient being up on third day), wound healed per primam, nnd bone solid. Nigbt after operation two sligbt attacks, but none since, and reakness of left arm almost disappeared, nnd restlessness nnd nervousness greatly diminished.

Mfay 27,1895 . Paresis of nrm and leg rapidly disappeared, nnd the child learned to talk. During first year after operntion, twice during attacks of acute indigestion, had a single convulsion, but of entirely different cbarncter to those formerly seen. Is still abnormnlly restless, nnd while running ahout occasionnl "jerks" nre observed. Otherwise cured.

Osteoplastic resection of skull for epilepsy. P., aged trrenty-six years ; Americnn; single. December 9, 1893. Family history good. Wben four years old fell, cnusing scalp wound in left parietal region. Pbysicinn put in one suture. Said to bave expressed fear of compression of brain. Continued bealtby until age of Eeventeen. Since that time has been suhject to epileptic fits. Patient and (adopted) motber state that fits occur about every eigbt or nine days, but friends atate that attacks are much more frequent, patient often not realizing that he bas hnd one. Before nn attack tbe patient states that he has n sense of "beat" passing upirnrd from ahdomen, through the chest to the head. This is followed hy general convulsions, with unconsciousness, followed by stupor.

On examination general good health; mind clear, but somenthat childish. In left parietal region is a scar ahout two and one-half incbes in length, commencing ahout one inch helow the vertex, passing ohliquely downward and hackward, Ahout middle of this cicntrix; scalp firmly adberent to hone, nnd distinct depression of hone.

Operation. Ether; usunl aseptic precautions; trephining over seat of depression; borsesboe incision with base down ward. Portion of hone, ahout two and one-balf' hy two inches, cut out witb cbisel and mallet; base left adberent to periosteum. Scalp found firmly adherent to bone, and dura mater to inferior surface of boue. Skull thickened on internal surface, corresponding to depression; no otber change; dura opened. Brnin protrudes ratber more thnn usual; otherwise normal. Dura closed by three catgut sutures. Sbeet of gold leaf iuterposed between durn nnd bone. Bone replaced. Scalp wound closed by continuous catgut sutures. Aseptic gauze nnd cotton dressing.

December 14th. Slight rise in temperature every evening since operation (bighest 101. ${ }_{10}^{8}$ ), hut utberwise condition good. Had two convulsions on the night following operation, but none since.

$30 \mathrm{~h}$. Dressing removed two weeks after operation. Complete per primam union, and bone solid. Had slight convulsion twelve nnd thirteen days nfter operation during night, and n very mild one on Decemher 28th. After first ordered sod. brom., gr. xc., at night nnd in tbree doses.

June 2, 1894. Cultures from scalp showed staphylococcus pyogenes albus.

May 27, 1895. Patient has mild convulsions at intervals of three 
weeks to a moatl. Says they do not last so long, and are not followed hy stupor, as hefore. Meatal condition much improved-apparently aormal.

Jacksonian epilepsy with mental aura; trephining. Rosa T., aged eight zears; American. Fehruary 1, 1894. Child has had strahismus since hirth. Family history good. When fourteea moaths old had attack of what was probahly cerehro-spiaal meaiagitis, with appareatly complete recovery. At age of three years fell hackward from halcony, some six to eight feet, strikiag left side of head oa a pile of bricks. Scalp wound of left parietal region, which healed readily. Ahout four moa ths later commeaced to have attacks of following character. Whea seemiag perfectly well child would hecome appareatly insaae, commeace to scream violeatly, and strike at any one near. Attacks usually accompanied hy spasmodic coatractions of left, sometimes of hoth arms; usually cersed whea child was beld and spoken to severely. Attacks generally followed hy unconsciousaess or semi-stupor, lasting a few miautes to several hours. Frequently complete a phasia, lastiag several hours after attack; if aot, always iadistinctaess of speech (" toague seemed thick"), and meatal confusion or coadition of apparent insanity. Attacks. occurred both hy day and night, duriag sleep or wakiag, without apparent excitiag cause, sometimes five or six times ia tweaty-four hours, sometimes only two or three times a week. Medical treatment (by bromides, etc), bad little or ao effect. Geaeral health and developmeat good, but child, while intelligeat and lenraing rapidly, restless, excitahle, and difficult to control. Complains of coastant paia, pointiag to frontal, both parietal and occipital regioas. Examia ation Bhows aotbing nbaormnl, except as nbove, nad a cicatrix of a small scalp wound not ndberent to the bone in left purietal region, nbout balf incb below estimated motor area of arm. No evidence of depression of bone. Etber; usual aseptic precautions. Omegn-sbaped incision of scalp, base dowa ward, over left motor area of arm; fragment of bone one and one half iaches vertically hy oae iach transverely removed eatirely with chisel and mallet. Dura aoa-ndherent, normnl; opened, and pia found somewhat odematous, vessels eagorged, and brain protrudiag more tban normal. Two catgut sutures of dura. Bone not replaced. Scalp wouad closed somewhat loosely hy coatiauous catgut sutures. Iodoform crystals. Iodoform and sterilized gauze aad cotton dressing.

Febricary 2d. No sbock or geaeral reaction followiag operatiou. Child had two mild spasmodic attacks of usual character duriag aight. Coadition exactly same as before operation, but says paia in the head has disa ppeared.

6th. Two slight attacks aight of Fehruary 2d; aoae siace. Mother Eays child is much quieter and less restless thaa hefore.

$14 t h$. Dressing removed; complete primary uaion.

26th. Whea seea two days ago, mother stated that siace operation child had three severe attacks aad a aumher of premonitioas a ot fullowed hy attack; much quieter and less restless.

Ifay 27, 1895. Patieat has occasional attacks oace in three or four weeks of similar character to those hefore operation, but much milder and aot followed hy stupor, aphasia, or iasanity. Still very restless aad excitahle, hut much less so than hefore, and constantly improving.

Trephining for Epilepsy. Katie K., aged twelve years and sevea 
months; American. August 23, 1894. When nhout ten months old, patient had attack of left hemiplegin, without known cnuse; no specific history. Partinlly recovered from this, hut nt the age of two years and seven months commenced to have severe general epilectic attacks. Since that time patient has scarcely grown or developed at all. Has never learned to walk, use her hands, or speak; and though there is no apparent paralysis of tongue or muscles of mastication, child has apparently forgotten how to chew, and only swnllows soft and liquid food. Passes urine and feces voluntarily, hut without knowing enough to call attention heforehand. Intelligence limited to recognizing memhers of family and indicating hunger and thirst hy putting out tongue. Has from five to twenty.five general convulsions every twenty-four hours, and requires constant attention.

Examination: Very anæmic, emnciated child, showing development of a child of four yenrs. Prresis of muscles of hoth legs aud arms, chiefly involving extensors, so that the hands a re held in flexed position, knees flexed, and feet extended. Rhachitic deformity of chest and curvature of lower end of left tihia. Had fairly well-developed and fairly formed head, except that pnrietal eminences are unusually prominent and there is corresponding depression at situation of posterior fontanelle.

Ether. Usual aseptic precautions. Omega-shaped incision with hase downward, over upper portion of motor centres on right side; found a thickening of hone, due to a deposit of soft cancellous houe, over a circular a rea, three-quarters of an inch in diameter at the upper and posterior portion of area of hone exposed. Removed with gouge und chisel nn urea of hone one and a half inches in diameter. Bone about hnlf as thick again as norwal, soft, and very vascular. Dura not specially adherent, hut vessels nuch enlarged, pin ndberent to durn, stripping off with it, and ressels much, enlarged. Durn closed with one silk suture. Bone not replaced. Scalp wound closed with continuous silk suture, iod. crystals, lodoform gnuze, and cotton dressing.

August $24 t h$. Little evidence of shock during or after operation. While coming out of ether had three slight convulsions; none since, and condition good. Niuch discharge of cerebro-spinal fluid through dressing, which, however, is dry and not changed.

September $6 t h$. Dressing removed. Complete primary union.

For nhout three months after operation no convulsions. Then hegan to have occasional attacks, hut single, nnd not more than once in two or three weeks. Parents thought intelligence improved, hut prohahly not. Died of unknown intercurrent disease a fter nhout seven mouths.

Epilepsy. Trephining. S., American, single, nged twenty-one years. April 29, 1894. Family history good. Was vell developed and healthy, except for one or two convulsions as bahy, until three years of nge. At that time had mild attack of diphtherin. From that time on commenced to have epileptic convulsions; mental development almost ceased nnd growth was grently retarderl. Has never lenrned to speak more than a few words, is entirely childish, nnd takes little notice of surroundings. Recognizes a few persons, hut slowly, and with difficulty. Has to he fed, and can only take soft food, having apparently not learned to chew; walks feehly, and generally with support, hut no paralysis. If watched carefully, will indicate when she desires to pass water or hnve movement of howels.

Ienstruation hegan ahout the age of fifteen, and normal since. Ap- 
petite good, sleeps well, and howels regular. Had general epileptic convulsions nfter diphtheria; nt first, as many as sixty a day; has taken almost constantly large doses of hrnmides, and convulsions have diminished to ahout five or six in twenty-four hours, occurring day and night.

Examination: Feehle, excessively anxmic nnd rather emaciated, having the appearance and development of a girl of fourtcen. IIental condition as ahove. Used as a child to complain uf unpleasant feeling in the stomach hefore an attack.

Operation. Right side of hend shnved and whole head close clipped. Usual aseptic precautions. Ether. Trephined on right side, in upper portion of motor area directly nver fissure af Rolando, using mallet, gouge, and chisel. Removed an aval piece of hone ahout tro and a half inches vertically and one and a half inches transversely. Found skull very much thickened, nhout trice normal extent. Dura normal, not adherent. Dura opened, marked congestion nf pia mater. Dura replaced with catgut suture. Bone not replaced; scalp loosely sutured with continuous catgut suture tn allow drainage, iodof. crystals, iodoform gauze, sterilized gauze, and cotton dressing.

April 30th. No shock; three slight couvulsions during night and forenoon. Free escape of stained cerehro-spinal fluid, wetting dressings. Covered with iodoform gauze and handnge.

May 15 $h$. Dressings removed. Complete primary union. During stay in hospital patient has heen very well and has gained flesh and hecome less ansemic. Has had n very fow slight convulsions, hut without losing consciousness.

28th. Patient was removed to her home May 16th. Parents stats that she was much hrighter, recognizing people mors readily, and connecting words in sentences, which she had never dons before, and having only one or two very slight convulsions. Am informed that yesterdny, without known cause, patient commenced to have violent convulsions, recurring every ten minutes, and died thnt evening. No autopsy.

Craniolomy for Idiocy. Dorn P., aged twenty-five months; California. Birth normal, no instruments being used. Wns fed on mother's milk until three months old, then cow's milk. She was bright nnd well until she was ten month's old, when she hnd a severe illness, lasting one week. Fever, vomiting, nud purging were mnrked, and a diagnosis of cholera. infantum was nade hy the nttending physician. After this illness the fontanelles, which had previously been open, closed rapidly, and the child has never shown the alightest intelligence since, does not recognize any of the family, or take any notice nf anything. She has never tried to crawl or speak, and her only voluntary action is sucking. Ever since the illness mentioned she has had nocturnal epilepsy, sometimes three fits in one night, and nearly always one. During the day she has attacks of "jerking" all over every ferv minutes; does not lose consciousuess, hut sometimes cries. She has inco-ordination, hut no paralysis; knee and ankle reflexes normal. The head is large, the hack being well developed, hut in the frontal nnd parietal regions it is greatly contracted.

Operation, Nfarch $16^{6} t$. Usual preparations and aseptic precautions. Ether. Left side of hesd operated upon. Pressure was made hy nn assistant over the temporal artery, thus controlling the hleeding. A large horseshoe-shaped incision was made, beginning one inch from the outer angle of the eye, emhracing the posterior one-third of frontal and anterior two-thirds of parietal regions, nnd being cnrried around to a 
point one-half inch anterior to nnd nn a level with the top of the enr. thus leaving a pedicle one inch wide, containing the tem poral artery, The highest part of the incision was within three fourths of an iach of the sacittal suture. The periosteum was remored from the hone in the line of the incision for a space nne-third of an inch wide, nad the hone was then removed to the same extent. In removing the hone a mallet and chisel were used to make the first npeniag down to the dura, and the hone was then rapidly cut away with the roageur forceps. The piece of hoae left under the skin-flap was fractured uader the pedicle, causing it to stand out, and leaving more room finr expnnsion of the hrain. The patient heing in good condition, a linear craniotomy was then doae, extendiag from the posterior superior part of the former one to within one-fourth of an inch of the necipital protuherance. The entire wound was then closed with a continuous suture of fae hlack silk, the stitches not heing drawn tight. A dressing nf idoform gauze, gauze roller, and cotton, and a starch handage were applied. The whole operation yas completed in forty minutes.

April $2 d$. The night of the nperation the patient's temperature rose to $105^{\circ}$, hut suhsided the next dny, and has heen normal ever since. There was complete primary union in the wound. There bave been no convulsions or jerking spells since. The mother and nurses think the child shows incressed intelligence. Right side of head operated on in precisely the same manner today. Operation completed in twenty minutes.

$3 d$. No local or general reaction.

13th. Stitches removed from wound on right aide nf bead to.day, complete primary union. No attack aince first uperation.

15th. Discharged.

Of these, the first five helong to the class of simple trephining for epilepsy, an operation long known and practised, but with very indefinite indications. Of these, one, the first, in which the epilepsy was complicated hy aphasia and paresis of one arm and leg, may be considered, I think, as cured. The second, third, and fourth, as greatly improved. While the fifth died several weeks after operation, prohahly from exhaustion due to convulsions following each other nlmost without intermission duriag several hours. As she had frequently had as mnny as sirty convulsions in one dny hefore this, it is hard to say how much the operation had to do with the fntal result.

In all, an omega-shaped flap was formed with the hase downwnrd, ahout two and a hnlf by twn inches in diameter, aad the hone rapidly cut out with gouge, chisel, and mallet. In only two cases was the hone replaced, after having hecome completely sepnrated from the flap during the operation. In all the durn mnter was opened to ohserve the condition of the hrain, and then replaced; the wound was closed without drainage, and healed per primam under one dressing. No shock or other u a pleasant symptoms followed in any case. I would urge that the operation may he done purely empirically, in all csses where the epileptic seizures are so frequent and violent as to make them a constant source of danger, anxiety, and cnre to the family of the pntient, and where 
medicinal agents fail to relieve. Further, in cages of traumatic origin, where there there are indications nf injury to some portion of the skull or hrain; and, lastly the hest recognized indication of all, in Jacksonian epilepsy, where symptoms, motor, Bensory, $\mathrm{nr}$ psychical, indicate that a definite portion of the cortex is diseased. In traumatic cases it is prohahly hest to follow the suggestion nf Starr (Brain Surgery, p. 26), that "when the injury and the localizing symptoms do not coincide, it is hetter to follow the localizing symptnms rather than the surgicnl injury." In localizahle epilepsy, Hnrsley's method may he followed of excising any portion of the cortex which can macroscopically he seen to be diseased, or excising the cortical centre, which, on the applicstion of a weak faradic current, is found to he the starting point $n$ a convulsion. The resulting paralysis may he permanent or temporary. Ohjection has heen made to this that the resulting hrain cicatrix will probahly form the starting point for new attacks. It seems, however, hardly probahle thnt a healthy cicatrix should he as serious n cause of irritation as softened and diseased tissue, when, however, no macroscopic evidence of disease is found, Starr advises not to excise. The statistics of the results of trephining for epilepsy are givenso fully hy Starr in his admirahle monograph on brain surgery, already referred to, that $I$ will not detain you with them now.

My sixth, and in some respects most inferesting case, is the only one strictly belonging to the class for which the operation of craniectomy or craniotomy was suggested hy Fuller (1878), Lane (1888), and Gueniot (1889), hut first performed by Lannelongue, and descrihed hy him in 1890 , an operation "intended to facilitate the expanion of the hrain, and, in consequence, the development of the intellectual faculties in microcephalics whose skulls are prematurely ossified, and in the most diverse intra-cranial lesions, hæmatemata, serous cyst, pachymeningitis externa, cerehral sclerosis, limited nr diffused." It is true that two of the preceding five operations were performed on idiots, hut only with the hope of diminishing the frequency and severity of their epileptic attacks, as their ages (twelve and twenty-one, reapectively) made any intellestual improvement hopeless. Lannelongue's operation was received at first with much enthusiasm, hut, as is usual, a reaction occurred. A number of deaths were reported, directly due to the nperation, and numerous other cases in which the patient survived the operation, hut no improvement followed. Perhaps the hardest hlow of all was struck hy A hraham Jacohi, at the International Congress in Rome, 1894, when he stated that he had collected thirty-three cases of craniotomy for idiocy and microcephnlus, and found that the results were al ways negative, nnd that a skull in Sach's possession proved the existence of a contractiun rather than enlargement of the cranium, ws the result of operation. As a result of these causes, the operation has heen almost ahandoned iu France and England, is strongly condemned in Germany, while Ameri- 
can surgeons are, I think, inclined to regard it as dangerous, unscientific, and useless.

To meet these ohjections and to show that the operation is in certain cases hoth reasonahly safe and justifinhle is the chief object of this paper.

The first and most serions ohjection urged is that the imbecility, epilepsy, and the nhnormal conditions ohserved in microcephalics are due to organic disease of the hrain, the cranial synostosis heing merely secondary, and that these conditions cannot be benefited hy operation. This question has heen very thoroughly atudied hy Starr, to whose monograph I must again refer. He divides the cases of imbecility, in which the question of trephining arise, into three clinical groups; the description of which would oceupy too much time. In regard to the pathological conditions present in these three groups, he states that "the lesions found are various in type, in origin, and in situntion, but ... first, that the difference in the clinical types is due to the varying situation of the lesion, rather than to its varying nature. Secondly, that the various processes of disease have, as a fairly uniform result, a condition of atrophy with sclerosis of the brain, which we may term sclerotic atropby." Finally, he concludes that many of the conditions described are clearly such as to be unaffected by opcration, but that, "on the other hand, there are conditions, such as mal-development of the cortes without gross lesion, in wbich it is possible that anytbing whicb may stimulate latent powers of growtb or may remove tbose influences wbich interfere with development might result in improvement," especially ss "the braiu is capable of growth nnd development until the age of twenty, if not longer." As it is impossible to determine the actual pathological condition before operation, we must fall back on clinical experience as a guide. Let us see then wbat clinical experience teacbes. We have already learned that Jacobi collected 33 cases in which no benefit resulted. Lannelongue stated at the Frencb Congress of Surgery, 1891, that he had operated 25 times, - with but one fatal result, and that the patients improved nfter the operation. His statement is too indefinite to allow of any conclusion. Starr gives in detnil 34 cases, with 14 deaths and 13 improved, or greatly improved. C. Beck, "Craniectomie (Lannelongue's operation) für Microcephalie und Idiotie" (Prager med. Wochensehrift, 1894, No. 39-45. Ref. Centralblatt für Chirurgie, No. 10,1895), has collected 72 cases, with a mortality of 17 per cent. In the remaining cases the results were as follows:

I. Complete, permanent improvement Cases.

II. Complete, improvement, with slight progress later 4

III. Slight improvement, which slowly progresses . 1

IV. No improvement . . . . . . . 1

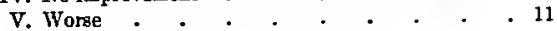

VI. No improvement, or reported too soon . $\quad . \quad 27$ 
While these results are not hrilliant, we must rememher that the conditions for which the operation is performed are otherwise entirely hopeless-the patients heing a hurden to themselves and to the community, and that even one success among a great many failures would justify the operation.

FIG. 1.

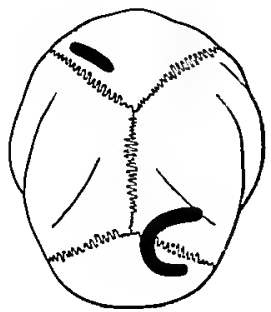

Fig. 3.

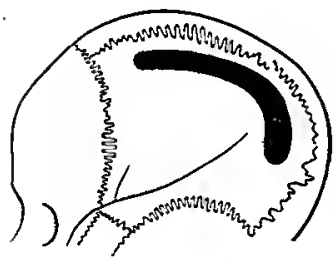

Fra. 5.

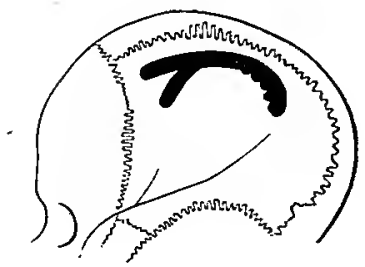

Fia. 2

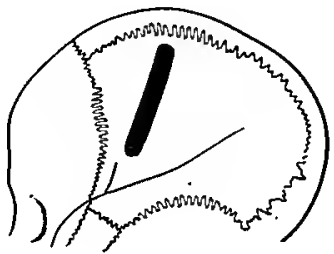

Fig. 4.

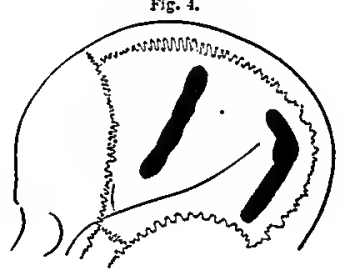

Fig. C.

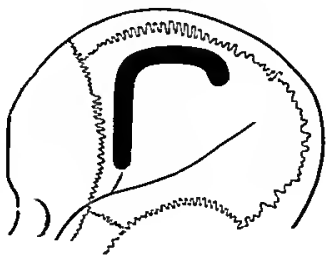

The next most important ohjection is that the operation does not actually increase the capacity of the skull, or even, as Jacohi tries to show, that it actually diminishes it. I think that this ohjection is justi- 
fied hy the character of the operations which have usually been performed. By linear craniotomy most snrgeons understand an operation consisting in the excision of a strip of hone, a quarter to a third of an

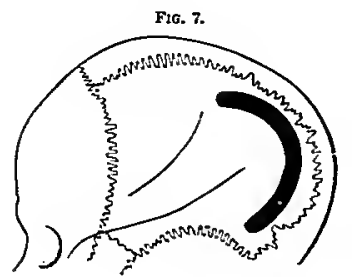

FIG. 9.

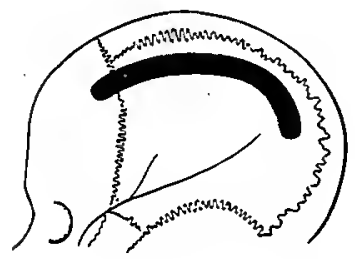

Escs. 1-10. Opcrative procedures of Lanpelongue.

Fir. 10 .
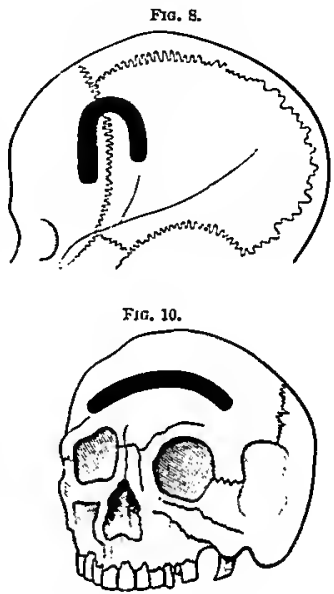

FIc. 11.

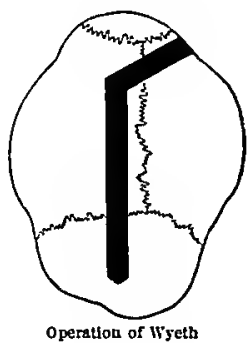

FIG. 12.

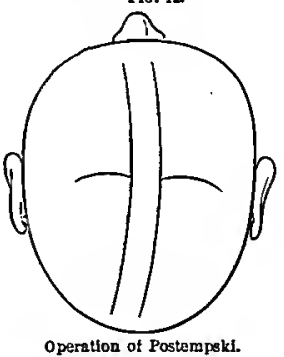

inch in width, extending from before hackward, on one or hoth sides of the median line. But a glance at the architecture of the skull will convince anyone that such an operation is little calculated to increase 
the capacity of the skull. As may he seen from the accompanying diagrams, taken from Dr. A. Chipanlt's encyclopedic work, Chirurgie Opératoire du Systime Nerveux, vol. i., most of Lannelongue's opera-

FIG. 13

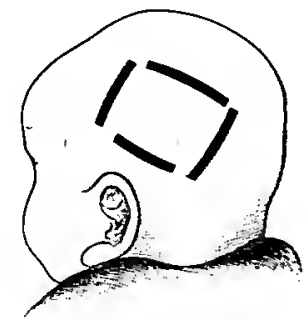

Operstion of Dumont. (From ChtPatit.)
Fro. 14.

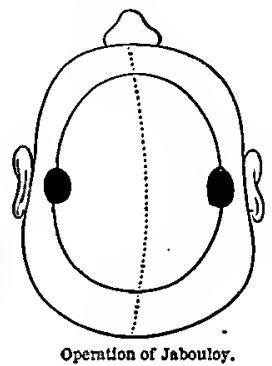

Fio. 15.

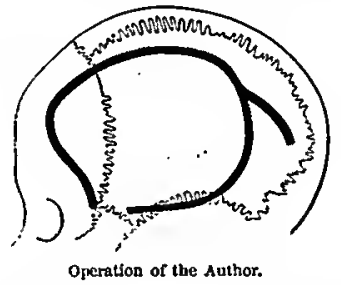

tiuns, "i lambeaux," as he calls them, accomplish even less than this. The only two operative procedures bitherto practised which seem to me in any way to meet the indications are those of Wyeth (Jfedical Record, Fehruary 21,1891, p. 232), (Diagram No. 12); and Dumont (Correspondenzblatt für Schweizer Aertzle, 1893, No. 23, p. 778. Rev. in The Medical News, January 13, 1894, p. 48), (Diagram No. 14), and in the first of these cases practically a complete cure resulted, while in the second the improvement was very great. Both operationg, however, have heen very generally condemned on account of the severity of the operative procedures, to which most patients would prohahly succumb. It was to ohviate these difficulties that $I$ devised the operation already described. The formation of the two anterior skin- and honeflaps rendered the operation hy compression of the temporal arteries, until clamps had heen applied, almost hloodless. By operating on one side 
first and on the second nfter an interval of two weeks, the danger of shock was greatly diminished. In my case, ns only the nuterior portion of the head was microcephalic, it seemed sufficient to cut out flaps in this region, hut otherwise I should not hesitnte to extend the operation to the posterior half instead of a simple linear craniotomy. I may mention that the mode of operation which I employed (mnking a smnll opening with gauge, chisel, nnd mallet), nnd cutting out the strip of hone with "rongenr" forceps, proved entirely satisfactory-the first operation occupying forty minutes and the second only twenty. With regard to the final result of the operation it is, of course, too early to make any statement, hut a report just received (June 26, 1895) from the mother states thnt the child has learned to sny mnmma and papn, is learning to walk, though slowly, plays with toys, and shows in other rays steady improvement. There have been no convulsions.

It would he easy for me to give an extensive bihliography of the authors consulted in preparing this pnper, hut the work bas heen so thoroughly done hy Starr (Brain Surgery), Dr. A. Chipault (Chirurgie Operaloire Systime Nerveux), and C. Beck, already mentioned, that I sball content myself by referring those interested to these authors.

Oetober 9, 1895. In regard to Case VI., Dora P., I have just learned from the mother that the child bas learned to walk and talk and shows constantly increasing intelligence. Dr. Comstock, the attending phyeician, reports that the result bas surpassed his most anguine bopes. I bare, since then, performed a similar but much more extensive operation in a case of microcepbalus, with complete idiocy, aged eight jears. There bas been little if any improvement in the mental condition, but the entire absence of any local or general results indicates that the operation is almost free from danger.

\section{CHRONIC DYSPEPSIA IN CHILDREN.}

BY J. Waltea Carr, MI.D., M.R.C.P. LoNd., F.R.C.S. ENG, ASSISTANT-FIYEICIAN TO THE BOYAL PREE ILOSPITAL AND TO TIE VICTORIA MOSTITAL FOI Cr:LDREs, LONDON.

Everyose recognizes djspepsia in adults in its protean and omnipresent forms, every medical man knows ita importance in infancy in association with errors of diet, hot between these two periods of life is one in which its frequency and the varied symptoms it produces are perhaps less commonly realized, altbough possibly it is hardly less prevalent than in adult life, and scarcely less important than in infancy. Childhood-especially hoybood-is a period when the digestive nnd assimilative powers are supposed to be at their maximum, when the 